\title{
Evaluasi Kebijakan Izin Lokasi dan Pertimbangan Teknis Pertanahan Pasca Penerapan Online Single Submission
}

\author{
(Evaluation of Location Permit Policy and Land Technical Considerations \\ After Implementation of Online Single Submission) \\ Ima Mayasari \\ Fakultas IImu Administrasi Universitas Indonesia \\ Gedung Prof. Dr. Mr. Prajudi Atmosudirdjo, Kampus UI Depok 16424 \\ Email: imamayasari@ui.ac.id
}

Naskah diterima: 27 Agustus 2019; revisi: 8 November 2019; disetujui: 8 November 2019

\begin{abstract}
Abstrak
Kebijakan izin lokasi dan pertimbangan teknis pertanahan pasca penerapan Online Single Submission (OSS), mengalami perubahan dalam tata kelola. Kementerian Agraria dan Tata Ruang/Kepala Badan Pertanahan Nasional (ATR/BPN) menerbitkan Peraturan Menteri ATR/BPN Nomor 14 Tahun 2018 tentang Izin Lokasi dan Peraturan Menteri ATR/BPN Nomor 15 Tahun 2018 tentang Pertimbangan Teknis Pertanahan. Penelitian ini terfokus pada evaluasi kebijakan izin lokasi dan pertimbangan teknis pertanahan pasca OSS baik retrospective (ex post) untuk melihat apa yang terjadi, dan apa perbedaannya dengan pengaturan sebelumnya maupun prospective (ex ante) untuk melihat apa yang akan terjadi dan apa yang seharusnya dilakukan. Metode penelitian menggunakan metode yuridis normatif. Hasil penelitian menunjukkan bahwa terdapat perbedaan dalam kewenangan pemberian izin lokasi, yang sebelumnya diterbitkan oleh Bupati/Walikota, Gubernur, dan Menteri sesuai dengan kewenangannya menjadi diterbitkan oleh Lembaga OSS berdasarkan Komitmen Pelaku Usaha (ex post) sementara itu secara prospective (ex ante) hal ini mendorong percepatan perizinan berusaha dan sinkronisasi tata ruang serta pemanfaatan ruang, didukung oleh kebijakan satu peta dan Satu Data Indonesia.

Kata Kunci: izin lokasi, pertimbangan teknis pertanahan, evaluasi kebijakan
\end{abstract}

\begin{abstract}
The location permits policy and the technical considerations of the land after the implementation of Online Single Submission (OSS), increase changes in governance. The Ministry of Agrarian Affairs and Spatial Planning/National Land Agency (ATR/ $B P N)$ issued Ministerial Regulation Number 14 of 2018 concerning Location Permit and Ministerial Regulation Number 15 of 2018 concerning Land Technical Considerations. This research focuses on evaluating the location permit policy after the implementation of OSS trying to be integrated electronically both retropectively (ex post) and prospective (ex ante). The research method uses the normative juridical method. The results showed that there were differences in the authority to grant location permits, which were previously issued by Regents/Mayors, Governors and Ministers in accordance with their authority to be issued by OSS Institutions based on Commitment (ex post) while prospective (ex ante) matters encouraging spatial synchronization.
\end{abstract}

Keywords: location permit, the technical considerations of the land, policy analysis 


\section{A. Pendahuluan}

Pelayanan perizinan berusaha terintegrasi secara elektronik atau yang dikenal dengan nama Online Single Submission (OSS), menjadi salah satu pencapaian dalam mereformasi bisnis proses perizinan berusaha-dengan menggunakan transformasi kemajuan teknologi-termasuk di dalamnya berkaitan dengan izin lokasi dan pertimbangan teknis pertanahan. Kecepatan waktu dalam pemberian perizinan berusaha, salah satunya terkendala oleh masalah izin lokasi dan pertimbangan teknis pertanahan.

Izin lokasi dan pertimbangan teknis pertanahan penting untuk dilakukan pembenahan dalam tata kelola (governance). Salah satu indikator yang menjadi penilaian daya saing Indonesia adalah kemudahan investasi. Langkah penting yang perlu dilakukan untuk kemudahan berusaha (ease of doing business) adalah melakukan reformasi regulasi yang berkaitan dengan investasi atau bisnis di Indonesia. Reformasi regulasi menjadi salah satu agenda penting yang perlu dilakukan Indonesia, untuk meningkatkan kualitas regulasi (high-quality regulations).

Pemerintah Indonesia telah berhasil mewujudkan reformasi regulasi dalam memfasilitasi pembangunan ekonomi. Reformasi regulasi telah dimulai sejak krisis moneter yang melanda Indonesia pada tahun 1998 dan dimulai oleh pemerintah di era reformasi. Sebelumnya, pada 1995, Dewan Organisation for Economic Co-operation and Development (OECD) meminta negara-negara anggotanya untuk meningkatkan kualitas regulasi. ${ }^{1}$

Berbagai langkah telah diambil untuk melakukan perbaikan terhadap peraturan di Indonesia, namun langkah ini mengalami hambatan dalam hal antara satu peraturan perundang-undangan dan peraturan perundang-undangan lainnya saling bertentangan. Ketidakharmonisan regulasi terjadi, oleh karena ego masing-masing sektor, menghasilkan regulasi yang dibuat tidak selaras dengan hukum dan regulasi di sektor lain.

Di bidang investasi, setiap sektor memiliki pengaturan untuk mekanisme perizinan di bidang investasi yang dibuka di Indonesia. Perizinan bisnis yang dikeluarkan oleh kementerian atau lembaga dan pemerintah daerahuntukmemulai, mengimplementasikan dan mengembangkan kegiatan bisnis, menghadapi masalah terkait dengan implementasinya. Restrukturisasi peraturan yang mendukung percepatan implementasi penting dilakukan, untuk mengurangi hambatan pengembangan kegiatan bisnis.

Peringkat kemudahan berusaha, yang diterbitkan oleh World Bank, dalam Doing Business Measuring Business Regulations, Ranking dan Skor Kemudahan Berusaha (Ease of Doing Business) di tahun 2019, Indonesia menempati peringkat ke-73 (tujuh puluh tiga) dalam Ease of Doing Business Rank. ${ }^{2}$ Sementara peringkat dalam Starting a Business, Indonesia menempati peringkat ke134 (seratus tiga puluh empat). Dibandingkan dengan negara serumpun, Indonesia masih 
berada di bawah negara-negara tersebut sebagaimana ditampilkan dalam Tabel 1 . Ranking dan Skor Ease of Doing Business Negara Serumpun, sebagai berikut: ${ }^{3}$

Tabel 1. Ranking dan Skor Ease of Doing Business Negara Serumpun

\begin{tabular}{ccc}
\hline Economy & $\begin{array}{c}\text { Ease of Doing } \\
\text { Business } \\
\text { Rank }\end{array}$ & $\begin{array}{c}\text { Starting a } \\
\text { Business }\end{array}$ \\
\hline Singapore & 2 & 3 \\
\hline Malaysia & 15 & 122 \\
\hline Thailand & 27 & 39 \\
\hline Brunei Darussalam & 55 & 16 \\
\hline Vietnam & 69 & 104 \\
\hline Indonesia & 73 & 134 \\
\hline
\end{tabular}

Sumber: https://www.doingbusiness.org/en/rankings.

Tabel di atas mengisyaratkan bahwa peringkat kemudahan berusaha dan starting a business di Indonesia masih berada di bawah negara serumpun seperti Singapura, Malaysia, Thailand, Brunei Darussalam, dan Vietnam. Dalam hal ini ekonomi diberikan peringkat berdasarkan kemudahan berusaha, dari 1-190. ${ }^{4}$ Kemudahan dalam melakukan usaha berarti lingkungan regulasi lebih kondusif untuk memulai dan mengoperasikan perusahaan. Peringkat ditentukan dengan mengurutkan skor agregat pada sepuluh topik, masing-masing terdiri dari beberapa indikator yang memberikan bobot yang sama untuk setiap topik. Pemeringkatan keseluruhan negara mengacu pada Mei $2018 .^{5}$
Kemudahan berusaha membantu menilai tingkat absolut kinerja regulasi dari waktu ke waktu. Hal ini menggambarkan terjadinya kesenjangan (gap) pada masing-masing ekonomi dari kinerja regulasi terbaik yang diamati pada masing-masing indikator pada semua ekonomi dalam contoh Doing Business sejak tahun 2005. Dengan demikian dapat dilihat kesenjangan antara kinerja ekonomi tertentu dan kinerja terbaik di setiap titik waktu dan menilai perubahan absolut dalam lingkungan regulasi ekonomi dari waktu ke waktu sebagaimana diukur oleh Doing Business. ${ }^{6}$

Dalam rangka menindaklanjuti ketentuan Pasal 32 ayat (2) huruf a dan Pasal 43 ayat (1) Peraturan Pemerintah Nomor 24 Tahun 2018 tentang Pelayanan Perizinan Berusaha Terintegrasi Secara Elektronik, serta untuk mendorong pertumbuhan ekonomi dan meningkatkan investasi di kawasan industri, dipandang perluuntukmelakukan penyesuaian pelayanan izin lokasi sebagaimana diatur dalam Peraturan Menteri Agraria dan Tata Ruang/Kepala Badan Pertanahan Nasional Nomor 5 Tahun 2015 tentang Izin Lokasi, ${ }^{7}$ sebagaimana telah diubah dengan Peraturan Menteri Agraria dan Tata Ruang/Kepala Badan Pertanahan Nasional Nomor 19 Tahun 2017 tentang Perubahan atas Peraturan Menteri Agraria dan Tata Ruang/Kepala Badan Pertanahan Nasional Nomor 5 Tahun 2015 tentang Izin Lokasi. ${ }^{8}$

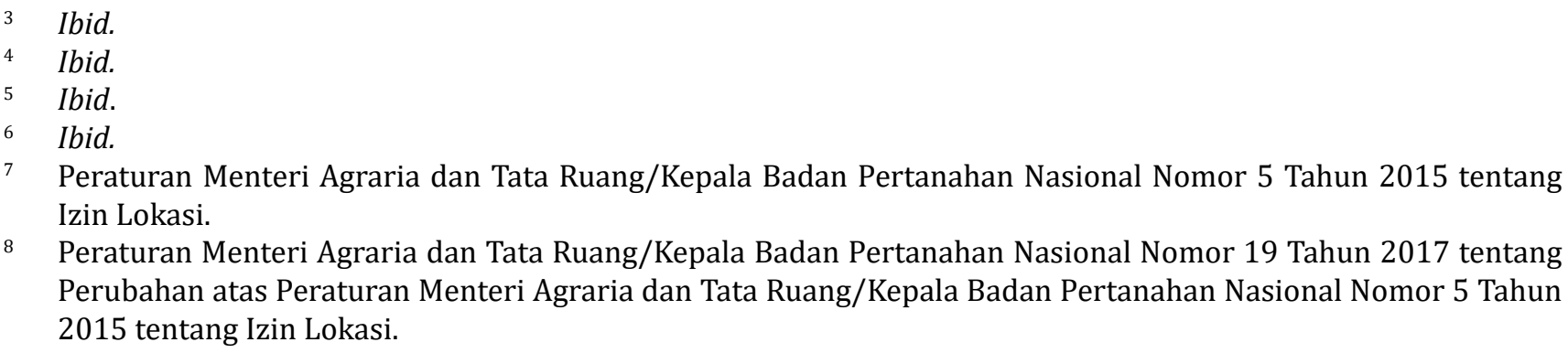

$8 \quad$ Peraturan Menteri Agraria dan Tata Ruang/Kepala Badan Pertanahan Nasional Nomor 19 Tahun 2017 tentang Perubahan atas Peraturan Menteri Agraria dan Tata Ruang/Kepala Badan Pertanahan Nasional Nomor 5 Tahun 2015 tentang Izin Lokasi. 
Selain izin lokasi, juga dilakukan penyesuaian regulasi pertimbangan teknis pertanahan yang diatur dalam Peraturan Kepala Badan Pertanahan Nasional Nomor 2 Tahun 2011 tentang Pedoman Pertimbangan Teknis Pertanahan Dalam Penerbitan Izin Lokasi, Penetapan Lokasi dan Izin Perubahan Penggunaan Tanah, ${ }^{9}$ dan Peraturan Kepala Badan Pertanahan Nasional Nomor 1 Tahun 2010 tentang Standar Pengaturan dan Pelayanan Pertanahan, ${ }^{10}$ serta Peraturan Menteri Agraria dan Tata Ruang/Kepala Badan Pertanahan Nasional Nomor 4 Tahun 2017 tentang Standar Pelayanan Kementerian Agraria dan Tata Ruang/Badan Pertanahan Nasional. ${ }^{11}$

Pada tanggal 13 Juli 2018, diterbitkan dua Peraturan Menteri Agraria dan Tata Ruang/ Kepala Badan Pertanahan Nasional merespon penerapan Online Single Submission (OSS). Dua Peraturan Menteri ATR/BPN yang diterbitkan yaitu (1) Peraturan Menteri Agraria dan Tata Ruang/Kepala Badan Pertanahan Nasional Nomor 14 Tahun 2018 tentang Izin Lokasi ${ }^{12}$; dan (2) Peraturan Menteri Agraria dan Tata Ruang/Kepala Badan Pertanahan Nasional Nomor 15 Tahun 2018 tentang Pertimbangan Teknis Pertanahan. ${ }^{13}$

Peraturan perundang-undangan yang menjadi landasan hukum terbitnya Permen ATR/BPR Nomor 14 Tahun 2018 antara lain: Undang-Undang Nomor 5 Tahun 1960 tentang Peraturan Dasar Pokok-Pokok Agraria, Undang-Undang Nomor 25 Tahun 2007 tentang Penanaman Modal, UndangUndang Nomor 26 Tahun 2007 tentang Penataan Ruang, Undang-Undang Nomor 18 Tahun 2012 tentang Pangan, Undang-Undang Nomor 3 Tahun 2014 tentang Perindustrian, Undang-Undang Nomor 23 Tahun 2014 tentang Pemerintahan Daerah.

Sementara itu juga terdapat Peraturan Pemerintah yang menjadi landasan penerbitan, antara lain Peraturan Pemerintah Nomor 16 Tahun 2004 tentang Penatagunaan Tanah, Peraturan Pemerintah Nomor 15 Tahun 2010 tentang Penyelenggaraan Penataan Ruang, Peraturan Pemerintah Nomor 64 Tahun 2016 tentang Pembangunan Perumahan MasyarakatBerpenghasilan Rendah, Peraturan Pemerintah Nomor 24 Tahun 2018 tentang Pelayanan Perizinan Berusaha Terintegrasi Secara Elektronik. Selanjutnya terdapat pula Peraturan Kepala Badan Pertanahan Nasional Nomor 1 Tahun 2010 tentang Standar Pelayanan dan Pengaturan Pertanahan, Peraturan Menteri Agraria dan Tata Ruang/ Kepala Badan Pertanahan Nasional Nomor 17 Tahun 2016 tentang Penataan Pertanahan di Wilayah Pesisir dan Pulau-Pulau Kecil, Peraturan Menteri Agraria dan Tata Ruang/ Kepala Badan Pertanahan Nasional Nomor 4 Tahun 2017 tentang Standar Pelayanan 
Kementerian Agraria dan Tata Ruang/Kepala Badan Pertanahan Nasional.

Transformasi kemajuan teknologi, menjadikan Indonesia memasuki era disrupsi (disruption era), di mana inovasi menjadi sangat penting. Perkembangan teknologi ini berpengaruh pula dalam peraturan perundang-undangan yang mengatur mengenai perizinan berusaha di Indonesia. Dalam melakukan evaluasi kebijakan izin lokasi dan pertimbangan teknis pertanahan pasca penerapan pelayanan perizinan berusaha terintegrasi secara elektronik, analisis kebijakan yang digunakan menggunakan Teori Analisis Kebijakan yang dikemukakan oleh William N. Dunn. ${ }^{14}$ Dua hal yang dilihat oleh William N. Dunn dalam melakukan analisis kebijakan yaitu retrospective (ex post) untuk melihat apa yang terjadi, dan apa perbedaanya dengan pengaturan sebelumnya maupun prospective (ex ante) untuk melihat apa yang akan terjadi dan apa yang harus dilakukan. ${ }^{15}$

Prospective policy analysis melibatkan produksi dan transformasi pengetahuan sebelum preskripsi dibuat. Prospektif, atau analisis ex ante, menandakan gaya operasi ekonom, sistem analisis, operasi peneliti, dan analisa pengambilan keputusan. Bentuk analisis prospektif disebut oleh William N. Dunn, sebagai analisis kebijakan (policy analysis). Analisis kebijakan mengandung pengertian analisa pengetahuan untuk mengambil alternatif kebijakan dan preferensi yang comparable, kuantitatif, dan kualitatif. ${ }^{16}$ Penelitian kebijakan digunakan dalam metode

Gambar 1. Form of Policy Analysis

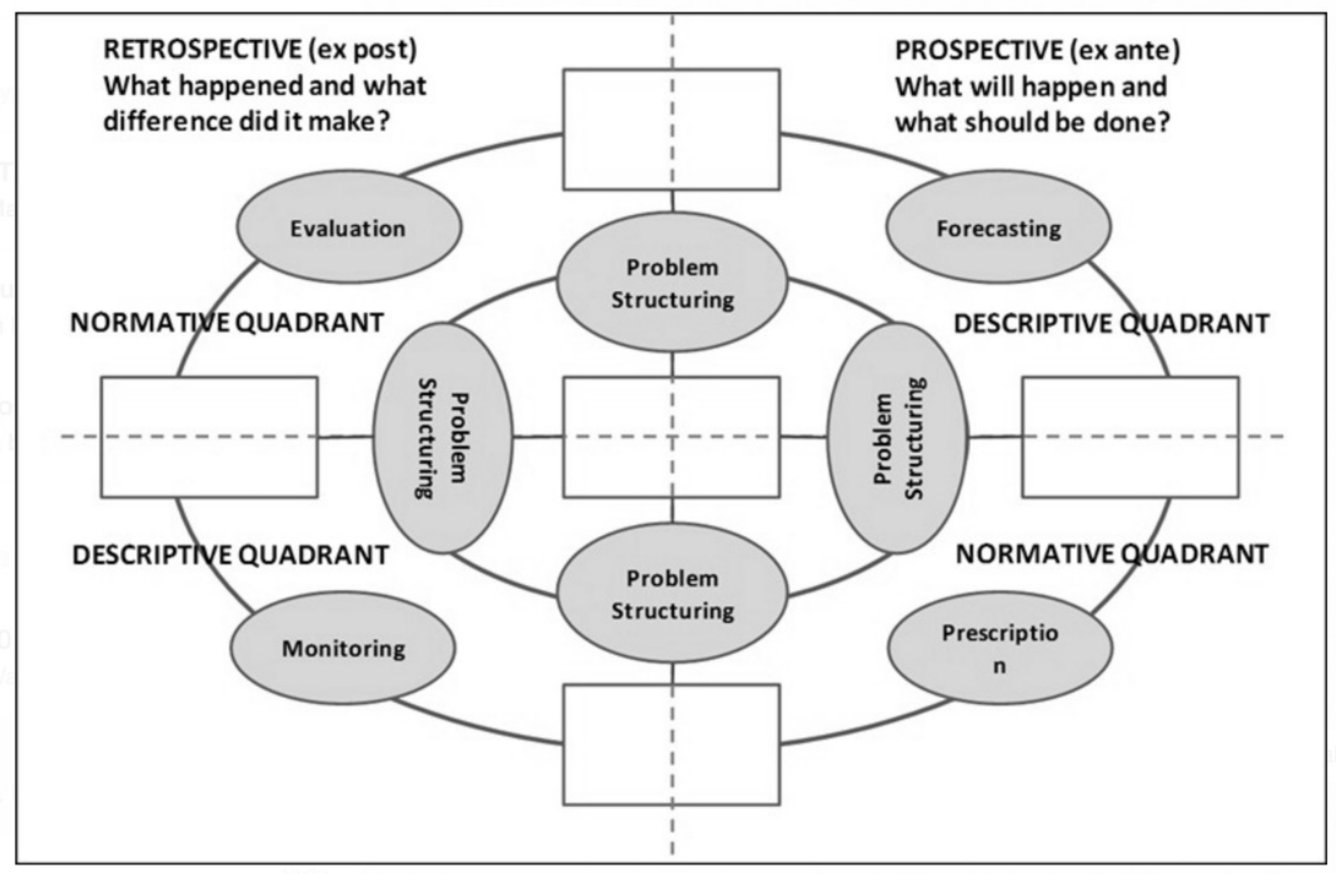

Sumber: William N. Dunn, Public Policy Analysis an Integrated Approach, 2018.

14 William N. Dunn, Public Policy Analysis an Integrated Approach, (New York: Routledge, 2018), hlm. 10-15.

15 Ibid., hlm. 10.

16 Walter Williams, Social Policy Research and Analysis: The Experience in the Federal Social Agencies, (New York: American Elsevier, 1971), hlm. 8, dalam William Dunn, ibid., hlm.10. 
ilmu sosial untuk menjelaskan fenomena. Namun, analisis prospektif sering datang dari kesenjangan antara pilihan solusi yang baik dan usaha untuk mengimplementasikannya. ${ }^{17}$

Sementara itu analisis kebijakan retrospective adalah solusi yang potensial. Bentuk dari ex post analysis menandakan produksi dan transformasi pengetahuan setelah kebijakan telah diimplementasikan. Analisis retrospective mencirikan gaya operasi beberapa kelompok analis:

Pertama, discipline-oriented analysts. Kelompok ini, sebagian besar terdiri dari pakar politik, ekonomi dan sosiologi, yang mengembangkan dan menguji disciplinebased theories tentang penyebab dan konsekuensi kebijakan. Kelompok ini tidak berfokus pada identifikasi variabel kebijakan yang tunduk atau tidak pada manipulasi. ${ }^{18}$

Kedua, problem oriented analysts. Kelompok ini, terdiri atas pakar politik, ekonomi, dan sosiologi yang mendeskripsikan penyebab dan konsekuensi dari kebijakan. Namun, problem oriented analysts kurang peduli dengan perkembangan dan pengujian teori yang penting untuk displin ilmu sosial. Kelompok ini lebih fokus pada mengidentifikasi variabel-variabel yang menjelaskan sebuah persoalan. Kelompok ini tidak fokus kepada obyek yang spesifik, oleh karena itu orientasinya bersifat umum, tidak khusus. ${ }^{19}$

Ketiga, applications-oriented analysts. Kelompok ketiga ini terdiri atas pakar politik terapan, ekonom terapan, sosiologi terapan dan psikologi terapan seperti public administration, social work dan evaluation research. Kelompok ini menjelaskan mengenai penyebab dan konsekuensi dari kebijakan dan kurang perhatian terhadap pengembangan dan pengujian teori. Kelompok ini sejalan dengan kelompok sebelumnya yang mengidentifikasi variabel-variabel manipulasi kebijakan yang berpotensi dapat mencapai tujuan khusus yang dapat dipantau dan dievaluasi dalam rangka mengevaluasi keberhasilan kebijakan. ${ }^{20}$

Selanjutnya berkaitan dengan descriptive dan normative analysis, dalam hal ini analisis kebijakan deskriptif berhubungan dengan descriptive decision theory, yang berkaitan dengan serangkaian proposisi logis yang konsisten menggambarkan atau menjelaskan tindakan. ${ }^{21}$ Tujuan utama dari teori dan kerangka kerja ini adalah menjelaskan, memahami dan memperkirakan kebijakan dengan mengidentifikasi pola-pola kausalitas-causal mechanisms. ${ }^{22}$ Dalam Gambar.1 dijelaskan bahwa descipriptive policy analysis dapat ditampilkan sebagai

\footnotetext{
Graham T. Allison, Essence of Decision: Explaining the Cuban Missile Crisis, (Boston: MA: Little, Brown, 1971), hlm. 267-268, dalam William Dunn, ibid., hlm.10.

18 James C. Coleman, Problems of Conceptualization and Measurement in Studying Policy Impact, in Public Policy Evaluation, ed. Kenneth M. Dolbeare, (Beverly Hills and London: Sage Publications, 1975), hlm. 25, dalam William Dunn, ibid., hlm.11.

19 Ibid.

20 Joshua D. Angrist and Jorn-Steffen Pischke, The Credibility Revolution in Empirical Economics: How Better Research Design Is Taking the Conout of Econometrics, Journal of Economic Perspectives 24, 2 (Spring, 2010) hlm. 3-30, dalam William Dunn, ibid., hlm.12.

21 Janet A. Weiss, Using Social Science for Social Policy, Policy Studies Journal 4 (Spring 1976): 237, dalam William Dunn, ibid., hlm.12.

22 Bower, Descriptive Decision Theory, h. 204, dalam William Dunn, ibid., hlm.12.
} 
sebuah sumbu yang bergerak dari lower left quadrant (monitoring) ke upper right quadrant (forecasting).

Normative policy analysis berkaitan dengan normative decision theory, yang mengacu pada serangkaian proposisi yang kosensisten secara logis, serta mengevaluasi atau menentukan tindakan. ${ }^{23}$ Dalam Gambar. 1 , normative policy analysis ditampilkan sebagai sumbu yang berjalan dari lower right quadrant (prescription) ke upper left quadrant (evaluation). Perbedaan pengetahuan yang dibutuhkan untuk menguji normative, dibedakan dari descriptive decision theories. Metode untuk mengevaluasi dan memperkirakan menyediakan pengetahuan mengenai policy performance dan preferred policies, atau kebijakan yang telah atau akan efisien secara optimal, oleh karena manfaatnya lebih besar daripada biaya, atau karena secara optimal adil dimana paling membutuhkan menjadi lebih baik. Satu hal yang paling penting dari normative policy analysis adalah proposisi bersandar pada nilai-nilai seperti efisiensi, efektifitas, keadilan, responsif, kebebasan, pencerahan, dan keamanan. ${ }^{24}$

Adapun berkaitan dengan problem structuring dan problem solving, siklus internal dan eksternal pada Gambar. 1, menyediakan hal perbedaan penting lain. Siklus internal merancang proses problem structuring. Prosedur problem structuring dirancang untuk mengidentifikasi elemen-elemen untuk menjelaskan permasalahan, tetapi tidak mengidentifikasi solusi. Apa elemen utama dari masalah? Apakah politik, ekonomi, sosial, etik atau kesemuanya? Bagaimana masalah distrukturkan, diorganisasi pada konfigurasi elemen khusus, seperti linear sequence atau sebuah sistem yang kompleks? Siapa pemangku kepentingan yang paling penting? Siapa yang mempengaruhi dan dipengaruhi oleh masalah? Apakah telah diindentifikasi tujuan yang tepat? Alternatif apa yang memungkinkan untuk mencapai tujuan? Apakah terdapat peristiwa tidak pasti yang seyogyanya diperhitungkan? Apakah telah memecahkan masalah secara benar? ${ }^{25}$

Sebaliknya, problem solving methods ditempatkan pada siklus luar dalam Gambar 1. Metode ini dirancang untuk menyelesaikan dibandingkan dengan menstrukturkan masalah. Metode seperti econometric forecasting atau benefit-cost analysis adalah problem solving methods. Metode ini menyusun pertanyaan tentang sejumlah variasi dari luaran yang dijelaskan oleh variabel independen. Berapa probabilitas untuk mendapatkan varian sebesar atau lebih besar dari yang diperoleh? Apa keuntungan dari perbedaan kebijakan? Apa manfaat atau imbalan yang diharapkan? ${ }^{26}$

Integrated policy analysis menghubungkan dua bagian pada Gambar. 1, keempat quadrant dan siklus internal dan eksternal. Bentuk analisis retrospective dan prospective bergabung dalam satu proses berkelanjutan.

23 Thomas D. Cook and Donald T. Campbell, Quasi-Experimentation: Design and Analysis Issues for Field Settings, (Boston, MA: Houghton Mifflin, 1979), Shadish, Cook, and Campbell, Experimental and Quasi Experimental Designs for Generalized Causal Inference, dalam William Dunn, ibid., hlm.12.

24 Harold D. Lasswell and Abraham Kaplan, Power and Society: A Framework for Political Inquiry, (New Haven, CT: Yale University Press, 1950), dalam William Dunn, ibid., hlm.14.

25 Ibid.

26 Ibid. 
Bentuk analisis descriptive dan normative juga dihubungkan, sebagai metode yang dirancang untuk merumuskan masalah dan memecahkannya. ${ }^{27}$ Integrated policy analysis menjembatani beberapa segmen dari multidisiplin analisis kebijakan, termasuk disiplin hukum.

Berdasarkan hal-hal tersebut di atas, penelitian ini terfokus pada evaluasi kebijakan izin lokasi dan pertimbangan teknis pertanahan pasca penerapan pelayanan perizinan berusaha terintegrasi secara elektronik atau dikenal dengan Online Single Submission, dengan perumusan masalah dalam penelitian yaitu: Bagaimana evaluasi kebijakan izin lokasi dan pertimbangan teknis pertanahan pasca penerapan pelayanan perizinan berusaha terintegrasi secara elektronik, baik dengan analisis retrospective (ex post) maupun analisis kebijakan prospective (ex ante)?

\section{B. Metode Penelitian}

Penelitian ini merupakan penelitian hukum normatif (normative legal research) dengan menggunakan pendekatan yuridis normatif (normative legal research). ${ }^{28}$ Datadata penelitian dikumpulkan melalui studi kepustakaan, dengan mengumpulkan dan menganalisis berbagai bahan hukum primer, bahan hukum sekunder dan bahan hukum tersier yang tersedia. ${ }^{29}$

Bahan hukum primer yaitu norma dasar atau kaidah, ketentuan atau peraturan dasar serta peraturan perundang-undangan serta bahan hukum sekunder yaitu bahan hukum yang memberikan penjelasan lebih lanjut mengenai bahan hukum primer berupa literatur, artikel jurnal, dan juga hasil penelitian yang relevan. Pengambilan data dilakukan dengan studi pustaka terhadap buku, artikel, hasil penelitian dan peraturan perundang-undangan. Analisis data dilakukan secara deskriptif kualitatif dalam melakukan pembahasan terhadap rumusan permasalahan penelitian.

Analisis data secara dekriptif juga dilakukan dengan menggunakan integrated policy analysis yang menghubungkan keempat quadrant sebagaimana tersaji dalam Gambar. 1 yaitu monitoring, evaluation, prescription dan forecasting. Bentuk analisis retrospective dan prospective bergabung dalam satu proses berkelanjutan. Bentuk analisis descriptive dan normative juga dihubungkan, sebagai metode yang dirancang untuk merumuskan masalah dan memecahkannya. Integrated policy analysis menjembatani beberapa segmen dari multidisiplin analisis kebijakan, terutama disiplin hukum.

\section{Pembahasan}

\section{Analisis Retrospective (Ex Post) terhadap Kebijakan Izin Lokasi dan Pertimbangan Teknis Pertanahan Pasca Penerapan OSS}

Dalam rangka percepatan dan peningkatan penanaman modal dan berusaha yang lebih efektif dan efisien, Pemerintah menerbitkan PP Nomor 24 Tahun 2018 tentang Pelayanan Perizinan Berusaha Terintegrasi Secara

Ibid.

28 Soerjono Soekanto dan Sri Mamudji, Penelitian Hukum Normatif: Suatu Tinjauan Singkat, Cet. 8, (Jakarta: PT Raja Grafindo Persada, 2006).

29 Johny Ibrahim, Teori dan Metodologi Penelitian Hukum Normatif, (Malang: Bayumedia Publishing, 2006), hlm. 295. 
Elektronik. Berdasarkan Pasal 43 ayat (1) PP Nomor 24 Tahun 2018, ketentuan lebih lanjut mengenai izin lokasi dan pertimbangan teknis pertanahan diatur dengan Peraturan Menteri yang menyelenggarakan urusan pemerintahan di bidang agraria. Lebih lanjut Pasal 43 ayat (2) menegaskan bahwa Peraturan Menteri sebagaimana dimaksud pada ayat (1) diterbitkan paling lama 15 (lima belas) hari sejak PP Nomor 24 Tahun 2018 diundangkan. Dengan demikian 15 (lima belas) hari setelah tanggal 21 Juni 2018, yaitu tanggal 13 Juli 2018, pemerintah wajib menerbitkan peraturan pelaksanaan (Peraturan Menteri) yang diamanatkan oleh Pasal 43 PP Nomor 24 Tahun 2018.

Tepat di tanggal 13 Juli 2018, Pemerintah mengundangkan dua Peraturan Menteri sebagai pelaksanaan Pasal 43 PP Nomor 24 Tahun 2018, yaitu (1) Peraturan Menteri Agraria dan Tata Ruang/Kepala Badan Pertanahan Nasional Nomor 14 Tahun 2018 tentang Izin Lokasi dan (2) Peraturan Menteri Agraria dan Tata Ruang/Kepala Badan Pertanahan Nasional Nomor 15 Tahun 2018 tentang Pertimbangan Teknis Pertanahan.

Permen ATR/BPN Nomor 14 Tahun 2018 dan Permen ATR/BPN Nomor 15 Tahun 2018 sekaligus mencabut dan menyatakan tidak berlaku lagi Peraturan Menteri Agraria dan Tata Ruang/Kepala Badan Pertanahan Nasional Nomor 5 Tahun 2015 tentang Izin Lokasi sebagaimana telah diubah dengan Peraturan Menteri Agraria dan Tata Ruang/ Kepala Badan Pertanahan Nasional Nomor 19 Tahun 2017 tentang Perubahan atas Peraturan Menteri Agraria dan Tata Ruang/ Kepala Badan Pertanahan Nasional Nomor 5
Tahun 2015 tentang Izin Lokasi, juga Peraturan Kepala Badan Pertanahan Nasional Nomor 2 Tahun 2011 tentang Pedoman Pertimbangan Teknis Pertanahan Dalam Penerbitan Izin Lokasi, Penetapan Lokasi dan Izin Perubahan Penggunaan Tanah dan Peraturan Kepala Badan Pertanahan Nasional Nomor 1 Tahun 2010 tentang Standar Pengaturan dan Pelayanan Pertanahan dan Peraturan Menteri Agraria dan Tata Ruang/Kepala Badan Pertanahan Nasional Nomor 4 Tahun 2017 tentang Standar Pelayanan Kementerian Agraria dan Tata Ruang/Badan Pertanahan Nasional.

Pengaturan izin lokasi dan pertimbangan teknis pertanahan yang diatur oleh Permen ATR/BPN Nomor 14 Tahun 2018 dan Permen ATR/BPN Nomor 15 Tahun 2018, dilakukan untuk mendukung percepatan perizinan berusaha terintegrasi secara elektronik atau OSS. Dalam kaitan dengan OSS, perizinan berusaha yang diterbitkan oleh lembaga OSS yang merupakan lembaga pemerintah nonkementerian yang menyelenggarakan urusan kepemerintahan di bidang penanaman modal untuk dan atas nama Menteri, Gubenur, Bupati/Wali Kota kepada pelaku usaha melalui sistem elektronik yang terintegrasi. ${ }^{30}$ Terhadap pelaku usaha yang memerlukan prasarana tetapi belum memiliki atau menguasai prasarana, Izin Usaha terbit setelah lembaga OSS menerbitkan:

(1) Izin Lokasi;

(2) Izin Lokasi Perairan;

(3) Izin Lingkungan;

(4) Izin Mendirikan Bangunan (IMB)

Izin lokasi menurut Pasal 1 angka Permen ATR/BPN Nomor 14 Tahun 2018 adalah izin

30 Indonesia, Peraturan Pemerintah tentang Pelayanan Perizinan Berusaha Terintegrasi Secara Elektronik, PP Nomor 24 Tahun 2018, Pasal 1 angka 4. 
yang diberikan kepada pelaku usaha untuk memperoleh tanah yang diperlukan untuk usaha dan/atau kegiatannya dan berlaku pula sebagai izin pemindahan hak dan untuk menggunakan tanah tersebut untuk keperluan usaha dan/atau kegiatannya. ${ }^{31}$ Pelaku usaha yang dimaksud dalam hal ini adalah perseorangan atau non perseorangan yang melakukan usaha dan/atau kegiatan pada bidang tertentu. ${ }^{32}$ Pelaku usaha perseorangan merupakan orang perorangan penduduk Indonesia yang cakap untuk bertindak dan melakukan perbuatan hukum. Sementara pelaku usaha non perseorangan terdiri atas: perseroan terbatas, perusahaan umum, perusahaan umum daerah, badan hukum lainnya yang dimiliki oleh negara, badan layanan umum, lembaga penyiaran, badan usaha yang didirikan oleh yayasan atau koperasi.
Izin lokasi dibedakan menjadi: (a) izin lokasi berdasarkan komitmen dan (b) izin lokasi tanpa komitmen. Pelaku usaha yang tidak memerlukan prasarana atau sudah menguasai atau memiliki prasarana untuk kegiatan berusaha maka tidak memerlukan izin lokasi, contoh: usaha bisnis online, pedagang retail, usaha yang berlokasi di pusat kegiatan komersial, dan seterusnya. ${ }^{33}$ Komitmen dalam hal ini adalah pernyataan pelaku usaha untuk memenuhi persyaratan izin usaha dan/atau izin komersial atau operasional. Komitmen yang wajib dipenuhi untuk izin lokasi berdasarkan komitmen adalah Pertimbangan Teknis Pertanahan (PTP) dan persetujuan Pemerintah Daerah.

Adapun alur mekanisme penerbitan izin usaha menurut PP Nomor 24 Tahun 2018 dapat digambarkan dalam Gambar. 2 Bagan Alur Mekanisme Penerbitan Izin Usaha sebagai berikut: ${ }^{34}$

Gambar. 2 Bagan Alur Mekanisme Penerbitan Izin Usaha

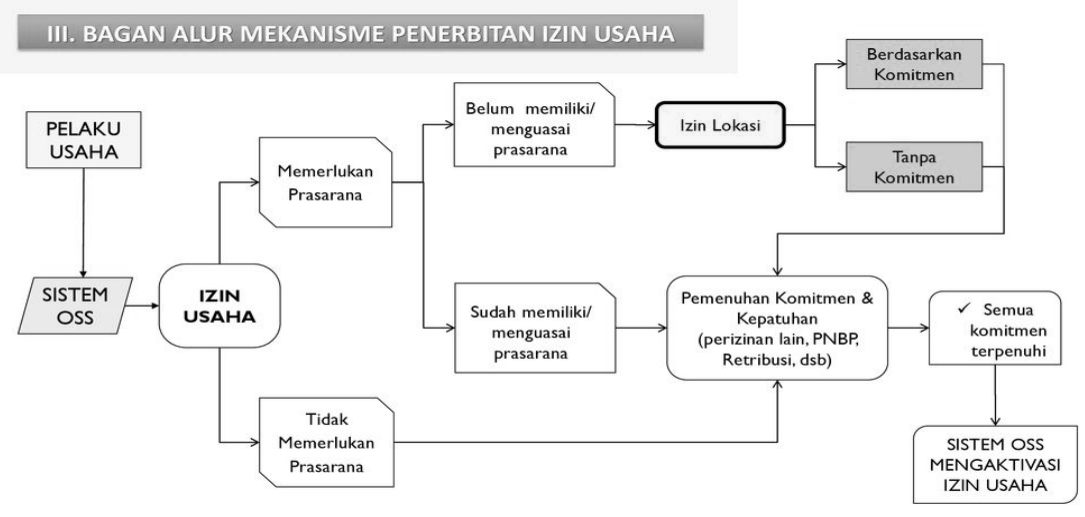

Sumber: Direktorat Jenderal Penataan Agraria Kementerian Agraria dan Tata Ruang/Badan Pertanahan Nasional, Agustus 2018.

31 Peraturan Menteri Agraria dan Tata Ruang/Kepala Badan Pertanahan Nasional Nomor 14 Tahun 2018 tentang Izin Lokasi, Pasal 1 angka 1.

32 Ibid., Pasal 1 angka 2.

33 Prasarana adalah segala sesuatu yang merupakan penunjang utama terselenggaranya suatu usaha dan/atau kegiatan seperti gedung, pabrik, unit pengolahan limbah, lahan/tanah. Pasal 1 angka 5 Peraturan Menteri Agraria dan Tata Ruang/Kepala Badan Pertanahan Nasional Nomor 14 Tahun 2018 tentang Izin Lokasi.

34 Direktorat Jenderal Penataan Agraria Kementerian Agraria dan Tata Ruang/Badan Pertanahan Nasional, Agustus 2018. 
Berdasarkan Gambar. 2 di atas, izin lokasi berdasarkan komitmen dan tanpa komitmen diproses berdasarkan Permen ATR/BPN Nomor 14 Tahun 2018 tentang Izin Lokasi dan Permen ATR/BPN Nomor 15 Tahun 2018 tentang Pertimbangan Teknis Pertanahan.
Selanjutnya Gambar. 3 Bagan Alur Mekanisme Penerbitan Izin Lokasi Berdasarkan Komitmen dan Gambar. 4 Bagan Alur Mekanisme Penerbitan Izin Lokasi Tanpa Komitmen, menjelaskan mengenai alur mekanisme penerbitan izin lokasi berdasarkan komitmen dan tanpa komitmen sebagai berikut: ${ }^{35}$

Gambar. 3 Bagan Alur Mekanisme Penerbitan Izin Lokasi Berdasarkan Komitmen
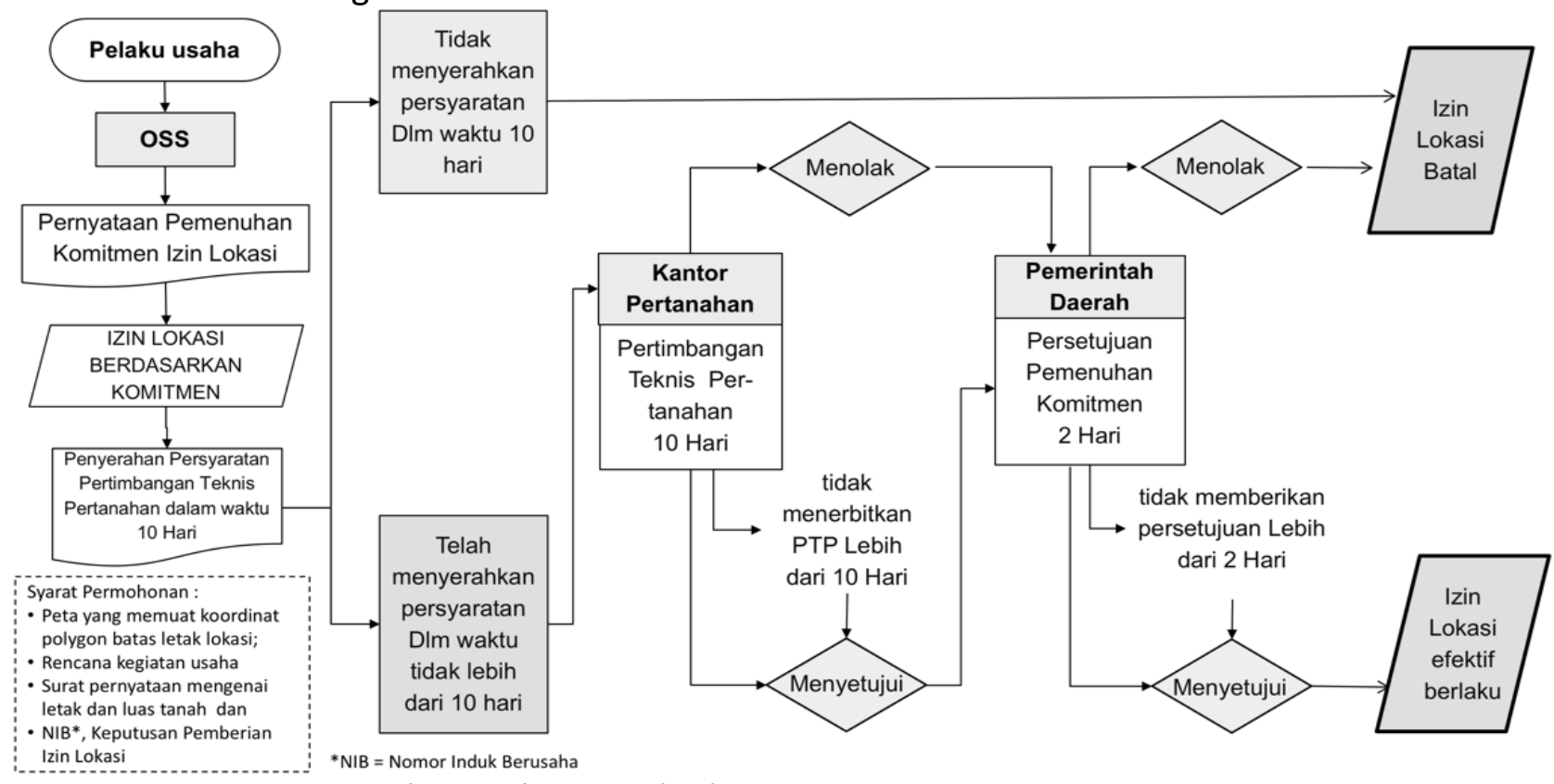

*NIB = Nomor Induk Berusaha

Sumber: Direktorat Jenderal Penataan Agraria Kementerian Agraria dan Tata Ruang/Badan Pertanahan Nasional, Agustus 2018.

Gambar. 4 Bagan Alur Mekanisme Penerbitan Izin Lokasi Tanpa Komitmen

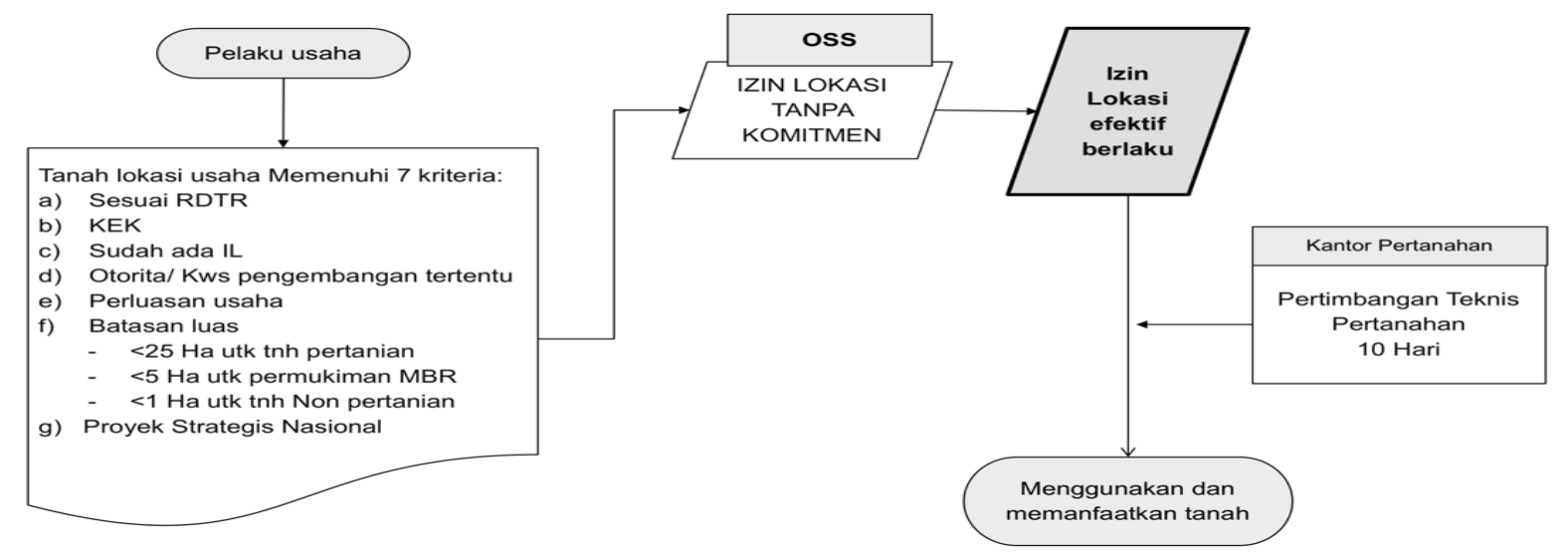

Sumber: Direktorat Jenderal Penataan Agraria Kementerian Agraria dan Tata Ruang/Badan Pertanahan Nasional, Agustus 2018. 
Gambar.3 mengisyaratkan bahwa izin lokasi berdasarkan Komitmen diterbitkan dengan terlebih dahulu menyertakan Pernyataan Pemenuhan Komitmen Izin Lokasi. Setelah diterbitkan Izin Lokasi Berdasarkan Komitmen, Pelaku usaha yang tidak menyerahkan persyaratan dalam waktu sepuluh hari maka izin lokasi batal, sebaliknya dalam hal pelaku usaha memenuhi persyaratan dalam waktu 10 hari maka izin lokasi efektif berlaku.

Gambar. 4 di atas mengisyaratkan bahwa pelaku usaha yang tanah lokasi usaha memenuhi tujuh kriteria yaitu: sesuai RDTR, sudah terdapat izin lokasi, otoritas atau kawasan pengembangan tertentu, perluasan usaha, batasan luasan dan proyek strategis nasional melalui lembaga OSS memperoleh izin lokasi tanpa komitmen, sehingga izin lokasi efektif berlaku dan Kantor Pertanahan memberikan pertimbangan teknis pertanahan dalam waktu sepuluh hari, kemudian pelaku usaha dapat menggunakan dan memanfaatkan tanah. Dengan demikian terdapat perbedaan tata kelola antara izin lokasi berdasarkan komitmen dan tanpa komitmen.

Permen ATR/BPN Nomor 14 Tahun 2018 menyebutkan bahwa izin lokasi diberikan untuk jangka waktu 3 (tiga) tahun sejak izin lokasi berlaku efektif. Perolehan tanah oleh pemegang izin lokasi harus diselesaikan dalam jangka waktu izin lokasi. Apabila dalam jangka waktu izin lokasi perolehan tanah belum selesai maka: (1) Izin lokasi dapat diperpanjang jangka waktunya selama 1 (satu) tahun, apabila tanah yang sudah diperoleh mencapai 50\% (lima puluh persen) atau lebih dari luas tanah yang ditunjuk dalam izin lokasi; (2) Izin lokasi tidak dapat diperpanjang apabila jangka waktu izin lokasi sebagaimana dimaksud pada ayat (1) berakhir dan perolehan tanah kurang dari 50\% (lima puluh persen) dari luas tanah yang ditunjuk dalam izin lokasi. Dengan demikian pemegang izin lokasi wajib melaporkan secara berkala setiap tiga bulan kepada Kepala Kantor Pertanahan mengenai perolehan tanah yang sudah dilaksanakan berdasarkan izin lokasi dan pelaksanaan penggunaan tanah tersebut. Tanah yang sudah diperoleh wajib didaftarkan pada Kantor Pertanahan setempat paling lambat satu tahun sejak berakhirnya masa berlaku izin lokasi.

Adapun kegiatan monitoring dan evaluasi dilakukan secara berjenjang oleh Kantor Wilayah dan Kantor Pertanahan terhadap: (a) perolehan tanah; (b) penggunaan dan pemanfaatan tanah; dan (c) pengamanan yang dilakukan oleh pelaku usaha terhadap tanah yang sudah diperoleh. Hasil monitoring dan evaluasi ini menjadi bahan pertimbangan dalam pembatalan izin lokasi.

Tabel. 2 Perbandingan Permen ATR/ BPN Nomor 5 Tahun 2015 jo. Permen ATR/ BPN Nomor 19 Tahun 2017 dengan Permen ATR/BPN Nomor 14 Tahun 2018 tentang Izin Lokasi, memperlihatkan perbandingan antara peraturan saat ini dan peraturan sebelumnya dalam bingkai analisis retrospective (ex post) $:^{35}$ 
Tabel. 2 Perbandingan Permen ATR/BPN Nomor 5 Tahun 2015 jo. Permen ATR/BPN Nomor 19 Tahun 2017 dengan Permen ATR/BPN Nomor 14 Tahun 2018 tentang Izin Lokasi

\begin{tabular}{|c|c|c|c|}
\hline No. & Uraian & $\begin{array}{l}\text { Permen ATR/BPN } \\
\text { Nomor } 5 \text { Tahun } 2015 \\
\text { jo Permen ATR/BPN } \\
\text { Nomor } 19 \text { Tahun } 2017\end{array}$ & Permen ATR/BPN Nomor 14 Tahun 2018 \\
\hline 1 & $\begin{array}{l}\text { Persyaratan } \\
\text { subyek }\end{array}$ & $\begin{array}{l}\text { Tidak memerlukan Nomor } \\
\text { Induk Berusaha (NIB) }\end{array}$ & Memerlukan NIB \\
\hline 2 & $\begin{array}{l}\text { Mekanisme } \\
\text { permohonan }\end{array}$ & $\begin{array}{l}\text { Pemohon datang langsung } \\
\text { ke kantor Pelayanan Terpadu } \\
\text { Satu Pintu (PTSP) }\end{array}$ & Melalui sistem OSS \\
\hline 3 & $\begin{array}{l}\text { Penunjukan lokasi } \\
\text { yang dimohon }\end{array}$ & Peta penunjuk lokasi & $\begin{array}{l}\text { - Melalui portal OSS: titik koordinat atau } \\
\text { onscreen } \\
\text { - Apabila sudah tersedia RDTR digital maka } \\
\text { izin lokasi diterbitkan secara otomatis. } \\
\text { - Apabila belum terdapat RDTR maka izin } \\
\text { lokasi diberikan dengan komitmen }\end{array}$ \\
\hline 4 & Penerbit izin lokasi & DPMPTSP/Bupati/Walikota & Lembaga OSS \\
\hline 5 & $\begin{array}{l}\text { Penandatanganan } \\
\text { izin lokasi }\end{array}$ & $\begin{array}{c}\text { Ka DPMPTSP/Bupati/ } \\
\text { Walikota }\end{array}$ & Kepala Lembaga OSS secara elektronik \\
\hline 6 & $\begin{array}{l}\text { Dokumen izin } \\
\text { lokasi }\end{array}$ & Berbentuk analog/kertas & Berbentuk elektronik yang dapat dicetak \\
\hline 7 & $\begin{array}{c}\text { Posisi } \\
\text { Pertimbangan } \\
\text { Teknis Pertanahan }\end{array}$ & $\begin{array}{l}\text { Sebelum izin lokasi } \\
\text { diterbitkan }\end{array}$ & $\begin{array}{l}\text { - Setelah izin lokasi diterbitkan berdasarkan } \\
\text { komitmen atau tanpa komitmen } \\
\text { - Pertimbangan Teknis Pertanahan sebagai } \\
\text { dasar izin lokasi berlaku efektif }\end{array}$ \\
\hline 8 & Posisi izin usaha & $\begin{array}{c}\text { Sebagai persyaratan izin } \\
\text { lokasi }\end{array}$ & Izin usaha terbit setelah terdapat izin lokasi \\
\hline 9 & $\begin{array}{c}\text { Batas waktu } \\
\text { pendaftaran tanah }\end{array}$ & Tidak diatur & $\begin{array}{l}\text { Wajib mendaftarkan tanah yang diperoleh } \\
\text { paling lambat satu tahun setelah berakhirnya } \\
\text { masa berlaku izin lokasi (Pasal 23) }\end{array}$ \\
\hline \multirow[t]{2}{*}{10} & \multirow[t]{2}{*}{ Kekuatan hukum } & \multirow{2}{*}{$\begin{array}{l}\text { Pertimbangan Teknis } \\
\text { Pertanahan sebagai } \\
\text { pertimbangan Pemerintah } \\
\text { Daerah dalam menerbitkan } \\
\text { izin lokasi. }\end{array}$} & $\begin{array}{l}\text { Pertimbangan Teknis Pertanahan sebagai } \\
\text { penentu berlaku atau ditolaknya izin lokasi } \\
\text { (Pasal } 15 \text { ) }\end{array}$ \\
\hline & & & $\begin{array}{l}\text { Pemerintah daerah menyetujuiataumenolak } \\
\text { izin lokasi berdasarkan Pertimbangan Teknis } \\
\text { Pertanahan }\end{array}$ \\
\hline
\end{tabular}

Sumber: Direktorat Jenderal Penataan Agraria Kementerian Agraria dan Tata Ruang/Badan Pertanahan Nasional, Agustus 2018.

Selanjutnya berdasarkan Tabel. 2, melalui Permen ATR/BPN Nomor 15 Tahun 2018, Pertimbangan Teknis Pertanahan diterbitkan oleh Kantor Pertanahan dalam rangka: (1) persetujuan atau penolakan izin lokasi; (2) pemberian perpanjangan atau pembaharuan 
hak atas tanah; (3) penegasan status dan rekomendasi penguasaan tanah timbul; atau (4) perubahan penggunaan dan pemanfaatan tanah. Adapun perbandingan pengaturan Pertimbangan Teknis Pertanahan berdasarkan pengaturan saat ini dan sebelumnya, dapat dilihat pada Tabel. 4 Perbandingan Perkaban Nomor 2 Tahun 2011 dengan Permen ATR/BPN Nomor 15 Tahun 2018 tentang Pertimbangan Teknis Pertanahan, sebagai berikut: ${ }^{36}$

Tabel. 3 Perbandingan Perkaban Nomor 2 Tahun 2011 dengan Permen ATR/BPN Nomor 15 Tahun 2018 tentang Pertimbangan Teknis Pertanahan

\begin{tabular}{|c|c|c|c|}
\hline No. & Uraian & PERKBPN Nomor 2 Tahun 2011 & Permen ATR/BPN Nomor 15 Tahun 2018 \\
\hline 1 & $\begin{array}{l}\text { Dasar } \\
\text { Menimbang }\end{array}$ & $\begin{array}{l}\text { PP Nomor } 16 \text { Tahun } 2004 \text { tentang } \\
\text { Penatagunaan Tanah }\end{array}$ & $\begin{array}{l}\text { - PP Nomor } 16 \text { Tahun } 2004 \\
\text { - PP Nomor } 24 \text { Tahun } 2018\end{array}$ \\
\hline 2 & Muatan & $\begin{array}{l}\text { Pertimbangan Teknis Pertanahan } \\
\text { dalam rangka: } \\
\text { - penerbitan izin lokasi } \\
\text { - penetapan lokasi } \\
\text { - izin perubahan penggunaan } \\
\text { tanah }\end{array}$ & $\begin{array}{l}\text { Pertimbangan Teknis Pertanahan dalam rangka: } \\
\text { - persetujuan atau penolakan izin lokasi; } \\
\text { - pemberian atau perpanjangan atau } \\
\text { pembaharuan hak atas tanah; } \\
\text { - penegasan status dan rekomendasi } \\
\text { penguasaan tanah timbul; atau } \\
\text { - perubahan penrggunaan dan pemanfaatan } \\
\text { tanah }\end{array}$ \\
\hline 3 & $\begin{array}{l}\text { Posisi } \\
\text { Pertimbangan } \\
\text { Teknis } \\
\text { Pertanahan }\end{array}$ & $\begin{array}{l}\text { - Terbit sebelum izin lokasi } \\
\text { diterbitkan oleh Kepala PTSP/ } \\
\text { Bupati/Walikota } \\
\text { - Sebagai dasar pertimbangan } \\
\text { penerbitan izin lokasi }\end{array}$ & $\begin{array}{l}\text { - Setelah izin lokasi diterbitkan oleh Lembaga } \\
\text { OSS } \\
\text { - Sebagai dasar pertimbangan izin lokasi efektif } \\
\text { berlaku }\end{array}$ \\
\hline 4 & Tata Cara & Pemohon datang langsung ke kantor & Melalui sistem OSS bagi Pelaku Usaha \\
\hline 5 & $\begin{array}{l}\text { Jangka Waktu } \\
\text { Penyelesaian }\end{array}$ & 14 (empat belas) hari & 10 (sepuluh) hari \\
\hline 6 & $\begin{array}{l}\text { Subyek/ } \\
\text { Pemohon }\end{array}$ & $\begin{array}{l}\text { Perusahaan, instansi pemerintah, } \\
\text { subyek pemohon lainnya yang sah }\end{array}$ & $\begin{array}{l}\text { - BUMN/BUMD/BUM Desa; } \\
\text { - Perseroangan atau Badan Hukum atau } \\
\text { - Pelaku Usaha }\end{array}$ \\
\hline 7 & Output & $\begin{array}{l}\text { Risalah dan Lampiran } 7 \text { Peta: } \\
\text { - Petunjuk Letak Lokasi; } \\
\text { - Penggunaan Tanah; } \\
\text { - Gambaran Umum Penguasaan } \\
\text { Tanah; } \\
\text { - Kemampuan Tanah; } \\
\text { - Kesesuaian Penggunaan Tanah; } \\
\text { - Ketersediaan Tanah; } \\
\text { - Pertimbangan Teknis Pertanahan }\end{array}$ & $\begin{array}{l}\text { Risalah, Pertimbangan Teknis Pertanahan, dan } \\
\text { satu Lampiran Peta }\end{array}$ \\
\hline 8 & Kewenangan & $\begin{array}{l}\text { Berjenjang Kantor Pertanahan- } \\
\text { Kantor Wilayah-Pusat }\end{array}$ & Kantor Pertanahan Kabupaten/Kota \\
\hline 9 & Pelaksana & Struktural & Struktural dan Fungsional \\
\hline
\end{tabular}

Sumber: Direktorat Jenderal Penataan Agraria Kementerian Agraria dan Tata Ruang/Badan Pertanahan Nasional, Agustus 2018.

36 Ibid. 
Berdasarkan Tabel. 3 tersebut di atas, dapat dilihat bahwa dari aspek posisi pertimbangan teknis pertanahan terdapat perbedaan penerbitannya, jika dalam Perkaban Nomor 2 Tahun 2011, diterbitkan sebelum izin lokasi diterbitkan oleh PTSP/ Bupati/Walikota, dan menjadi pertimbangan dalam penerbitan izin lokasi. Sedangkan dalam Permen ATR/BPN Nomor 15 Tahun 2018, diberikan setelah izin lokasi diterbitkan oleh Lembaga OSS dan sebagai dasar pertimbangan izin lokasi efektif berlaku. Kemudian dalam tata cara penerbitannya, izin lokasi diterbitkan melalui OSS bagi Pelaku Usaha. Jangka waktu pelaksanan pun lebih singkat dari 14 (empat belas) hari menjadi 10 (sepuluh) hari. Selanjutnya berkaitan dengan kewenangan tanpa dilakukan secara berjenjang, artinya saat ini hanya diproses melalui Kantor Pertanahan Kabupaten/Kota. Berikut ini dalam Gambar. 5 dan Gambar. 6 sebagai berikut:
Berdasarkan Gambar. 5 di atas, dapat dilihat bahwa proses pertimbangan teknis pertanahan dilakukan dengan melalui proses pengajuan berkas permohonan pada loket pelayanan/OSS, kemudian Tim Pertimbangan Teknis Pertanahan melaksanakan peninjauan lokasi, pengolahan data dan analisis, rapat pembahasan, penyusunan risalah dan peta, serta penetapan, untuk kemudian Kepala Kantor Pertanahan memberikan pertimbangan teknis pertanahan yang selanjutnya disampaikan kepada Bupati/ Walikota/Ka. PTSP untuk mendapatkan keputusan persetujuan/penolakan izin lokasi.

Gambar.5 Alur Proses Pertimbangan Teknis Pertanahan dalam rangka Persetujuan atau Penolakan Izin Lokasi Berdasarkan Komitmen

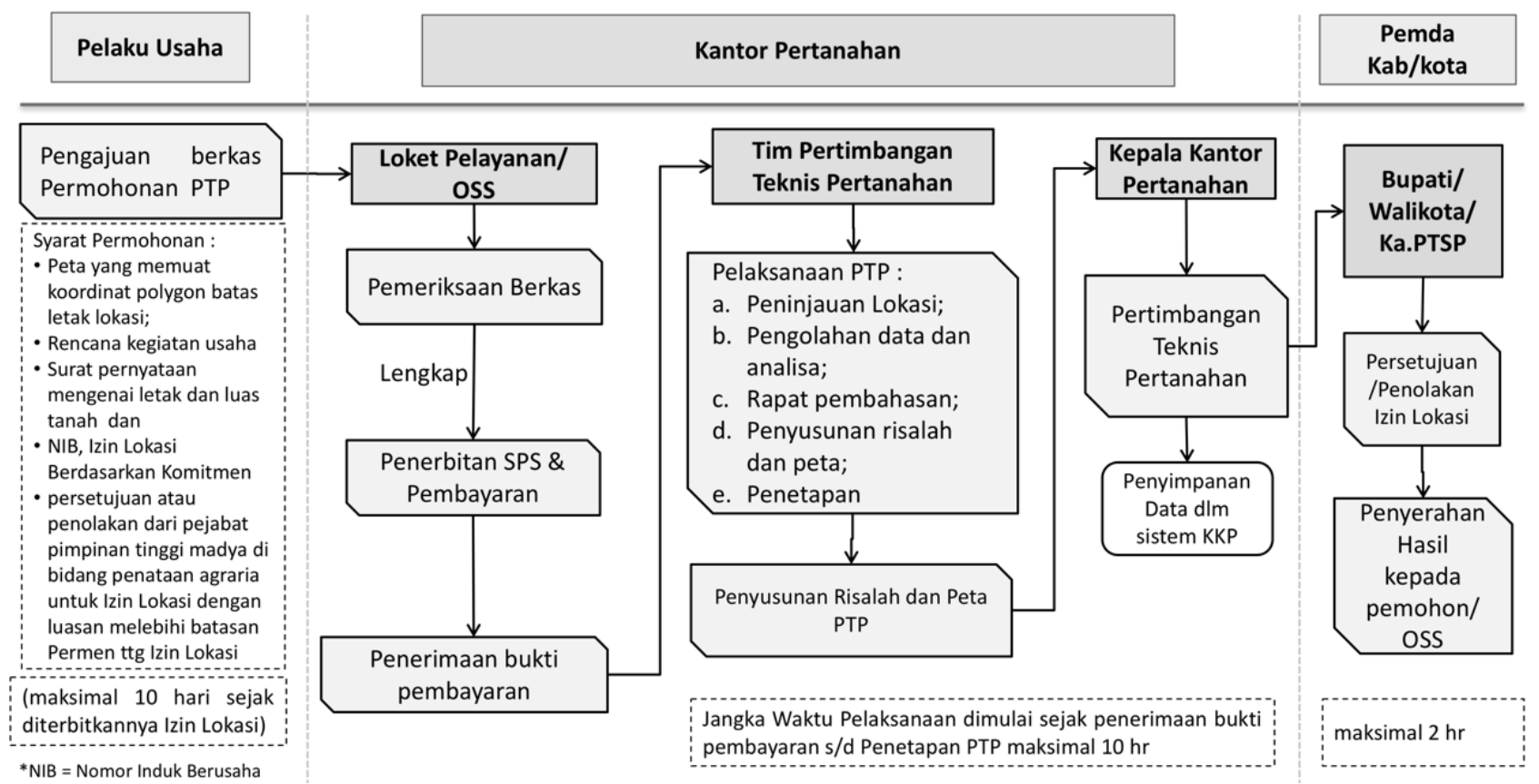

Sumber: Direktorat Jenderal Penataan Agraria Kementerian Agraria dan Tata Ruang/Badan Pertanahan Nasional, Agustus 2018. 
Gambar.6 Alur Proses Pertimbangan Teknis Pertanahan dalam rangka Persetujuan atau Penolakan Izin Lokasi Tanpa Komitmen

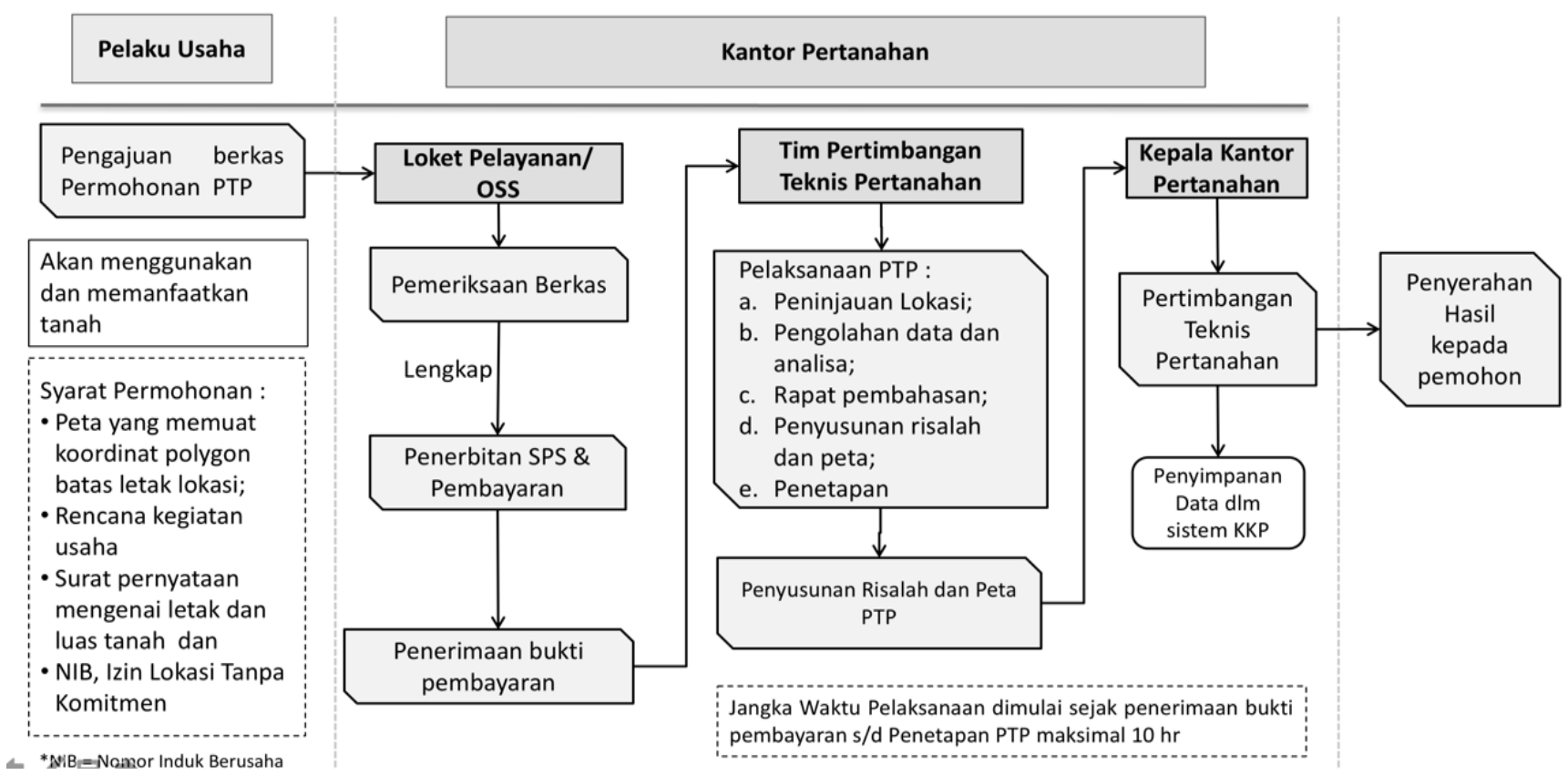

Sumber: Direktorat Jenderal Penataan Agraria Kementerian Agraria dan Tata Ruang/Badan Pertanahan Nasional, Agustus 2018.

Gambar. 6 mengisyaratkan bahwa Pertimbangan Teknis Pertanahan Pasca dalam rangka persetujuan atau penolakan izin lokasi tanpa komitmen terlebih dahulu dilakukan dengan pengajuan berkas permohonan Pertimbangan Teknis Pertanahan melalui loket pelayanan/OSS untuk kemudian Tim Pertimbangan Teknis Pertanahan menyusun risalah dan peta Pertimbangan Teknis Pertanahan dan disampaikan kepada Kantor Pertanahan dan selanjutnya menyerahkan hasil kepada Pemohon (Pelaku Usaha). Tentunya dengan Permen ATR/BPN Nomor 15 Tahun 2018, Pertimbangan Teknis Pertanahan diterbitkan dengan lebih efisien dari sisi proses dan waktu yang meningkatkan optimalisasi dalam pelayanan, dimana manfaat yang diberikan lebih besar dibandingkan dengan biaya. Kebijakan ini bersandar pada nilainilai seperti efisiensi, efektifitas, keadilan, responsif, kebebasan, pencerahan, dan keamananan.

\section{Analisis Prospective (Ex Ante) terhadap Kebijakan Izin Lokasi dan Pertimbangan Teknis Pertanahan Pasca Penerapan Pelayanan Perizinan Berusaha Terintegrasi Secara Elektronik}

Tantangan yang dihadapi dalam pelaksanaan OSS adalah belum tersedianya Rencana Detail Tata Ruang (RDTR). Percepatan penyusunan RDTR dilakukan untuk mendukung pelaksanaan OSS. Rencana Detail Tata Ruang ini ditujukan sebagai dasar perizinan pemanfaatan ruang, seperti tercantum di dalam Undang-Undang Nomor 26 Tahun 2007 tentang Penataan Ruang. Saat ini masih sedikit kabupaten dan kota yang memiliki RDTR. Sehingga, percepatan RDTR ini akan dilaksanakan di 100 hingga 
140 kabupaten/kota dari jumlah sebanyak 250 daerah tingkat II, di mana 80-90 persen investasi terkonsentrasi di dalamnya. ${ }^{37}$

Selanjutnya, perkembangan teknologi yang berbeda-beda antara daerah, menjadikan penerapan izin lokasi dan pertimbangan teknis pertanahan agak sulit dilakukan pada daerah yang sulit memperoleh akses terhadap informasi teknologi. Tantangan lainnya adalah belum diimplemetasikannya OSS di seluruh daerah di Indonesia.

Percepatan kebijakan satu peta (one map policy) dengan sinkronisasi peta di Indonesia, menjadi kebijakan yang strategis manfaatnya, terutama jika Indonesia memasuki e-Government dalam kegiatan pemerintahan. Lebih lanjut, melalui Peraturan Presiden Nomor 39 Tahun 2019 tentang Satu Data Indonesia, diharapkan data spasial dapat mempercepat pemberian izin lokasi dan pertimbangan teknis pertanahan tanpa komitmen, yang dapat mempercepat bisnis proses perizinan berusaha di Indonesia, dalam rangka peningkatan daya saing Indonesia.

\section{Penutup}

Berdasarkan hal-hal tersebut di atas dapat disimpulkan bahwa dengan adanya Permen terdapat perbedaan antara pengaturan izin lokasi dan pertimbangan teknis pertanahan sebelum dan sesudah pelaksanaan OSS, melalui Permen ATR/BPN Nomor Nomor 14 Tahun 2018 tentang Izin Lokasi dan Peraturan Menteri ATR/BPN Nomor 15 Tahun 2018 tentang Pertimbangan Teknis Pertanahan. Dalam hal ini Lembaga OSS menjadi lembaga yang menerbitkan izin lokasi, yang sebelumnya diterbitkan oleh Bupati/Walikota, Gubernur, dan Menteri sesuai dengan kewenangannya (ex post). Prosedur dalam penerbitannya pun lebih mudah dengan waktu penyelesaian yang lebih singkat serta menciptakan kepastian hukum bagi pelaku usaha, oleh karena pelaku usaha dapat memanfaatkan pelayanan OSS untuk memproses izin lokasi dan pertimbangan teknis pertanahan baik dengan komitmen maupun tanpa komitmen. Sementara itu secara prospective (ex ante) hal ini mendorong percepatan perizinan berusaha, dan sinkronisasi tata ruang dan pemanfaatan ruang, didukung oleh kebijakan satu peta (one map policy) dan satu data Indonesia (one data).

Rekomendasi atau arah kebijakan ke depan yang direkomendasikan dalam penulisan ini adalah penting untuk melakukan koordinasi antara berbagai kepentingan (stakeholders) dalam penerapan izin lokasi dan pertimbangan teknis pertanahan pasca pelaksanaan OSS. Tentunya hal ini dapat mendukung reformasi pertanahan di Indonesia, dan tentunya menciptakan kepastian hukum dan kepastian investasi di Indonesia.

\section{Daftar Pustaka}

\section{Buku}

Allison, Graham T, Essence of Decision: Explaining the Cuban Missile Crisis, (Boston: MA: Little, Brown, 1971).

Coleman, James C, Problems of Conceptualization and Measurement in Studying Policy Impact, in Public Policy Evaluation, ed. Kenneth M. Dolbeare, (Beverly Hills and London: Sage Publications, 1975).

CNN Indonesia, Izin Investasi Terpadu, Rencana Detail Tata Ruang Dikebut, https://www.cnnindonesia.com/ ekonomi/20180628212632-92-309920/izin-investasi-terpadu-rencana-detail-tata-ruang-dikebut, diakses 17 Agustus 2019. 
Cook, Thomas D and Donald T. Campbell, QuasiExperimentation: Design and Analysis Issues for Field Settings (Boston, MA: Houghton Mifflin, 1979).

Dunn, William N, Public Policy Analysis An Integrated Approach, (New York: Routledge, 2018).

Lasswell, Harold D. and Abraham Kaplan, Power and Society: A Framework for Political Inquiry, (New Haven, CT: Yale University Press, 1950).

Williams, Walter, Social Policy Research and Analysis: The Experience in the Federal Social Agencies, (New York: American Elsevier, 1971).

\section{Makalah/Jurnal/ Artikel/Hasil Seminar}

Janet A. Weiss, "Using Social Science for Social Policy", Policy Studies Journal 4, (Spring, 1976). Joshua D. Angrist and Jorn-Steffen Pischke, "The Credibility Revolution in Empirical Economics: How Better Research Design is Taking the Conout of Econometrics", Journal Of Economic Perspectives 24, 2 (Spring, 2010).

\section{Internet}

CNN Indonesia, "Izin Investasi Terpadu, Rencana Detail Tata Ruang Dikebut", https://www.cnnindonesia.com / ekonomi/20180628212632-92-309920/izininvestasi-terpadu-rencana-detail-tata-ruangdikebut, (diakses 17 Agustus 2019).

Direktorat Jenderal Penataan Agraria Kementerian Agraria dan Tata Ruang/Badan Pertanahan Nasional, "Peraturan Menteri Agraria dan Tata Ruang/Kepala Badan Pertanahan Nasional Nomor 14 Tahun 2018 tentang Izin Lokasi dan Nomor 15 Tahun 2018 tentang Pertimbangan Teknis Pertanahan," https://slideplayer.info/ slide/15741769/, (diakses 17 Agustus 2019).

OECD, "Ringkasan Eksekutif Kajian OECD mengenai Reformasi Regulasi Indonesia Memperkuat Koordinasi dan Menghubungkan Pasar", https://www.oecd.org/gov/regulatory-policy/ executive\%20summary\%20INDO\%20with\%20 cover\%20for\%20Internet.pdf, (diakses 17 Agustus 2019).

The World Bank, "Doing Business Measuring Business Regulations", https://www. doingbusiness.org/, (diakses 17 Agustus 2019).

\section{Peraturan}

Peraturan Pemerintah Nomor 24 Tahun 2018 tentang Pelayanan Perizinan Berusaha Terintegrasi Secara Elektronik.

Peraturan Menteri Agraria dan Tata Ruang/Kepala Badan Pertanahan Nasional Nomor 5 Tahun 2015 tentang Izin Lokasi.

Peraturan Menteri Agraria dan Tata Ruang/Kepala Badan Pertanahan Nasional Nomor 19 Tahun 2017 tentang Perubahan atas Peraturan Menteri Agraria dan Tata Ruang/Kepala Badan Pertanahan Nasional Nomor 5 Tahun 2015 tentang Izin Lokasi.

Peraturan Menteri Agraria dan Tata Ruang/Kepala Badan Pertanahan Nasional Nomor 4 Tahun 2017 tentang Standar Pelayanan Kementerian Agraria dan Tata Ruang/Badan Pertanahan Nasional.

Peraturan Menteri Agraria dan Tata Ruang/Kepala Badan Pertanahan Nasional Nomor 14 Tahun 2018 tentang Izin Lokasi.

Peraturan Menteri Agraria dan Tata Ruang/ Kepala Badan Pertanahan Nasional Nomor 15 Tahun 2018 tentang Pertimbangan Teknis Pertanahan.

Peraturan Kepala Badan Pertanahan Nasional Nomor 1 Tahun 2010 tentang Standar Pengaturan dan Pelayanan Pertanahan

Peraturan Kepala Badan Pertanahan Nasional Nomor 2 Tahun 2011 tentang Pedoman Pertimbangan Teknis Pertanahan Dalam Penerbitan Izin Lokasi, Penetapan Lokasi dan Izin Perubahan Penggunaan Tanah. 